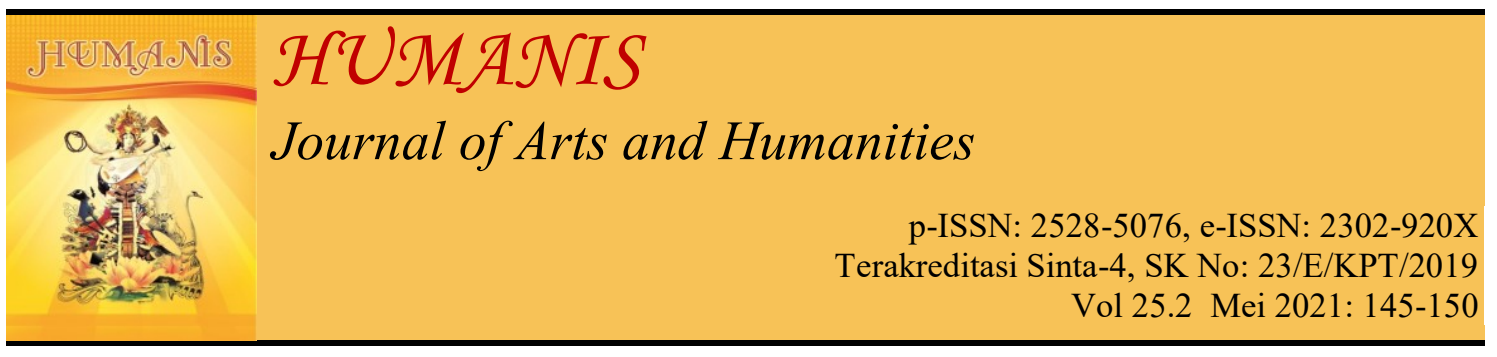

\title{
The Investigation of Request Strategies By EFL Learners of The International Institute of Tourism and Business Denpasar
}

\author{
Gede Eka Wahyu ${ }^{1}$, Ni Putu Evi Wahyu Citrawati ${ }^{2}$ \\ ${ }^{1}$ Institut Pariwisata dan Bisnis Denpasar, Denpasar, Bali, Indonesia \\ ${ }^{2}$ Universitas Udayana, Denpasar, Bali, Indonesia \\ Correspondence e-mail: ${ }^{1}$ eka.stpbispb14@gmail.com , \\ 2eviwahyu78@gmail.com
}

\begin{tabular}{l} 
Article Info \\
\hline Submitted: $25^{\text {th }}$ February 2021 \\
Revised: $31^{\text {st }}$ March 2021 \\
Accepted: $7^{\text {th }}$ April 2021 \\
Keywords: communicative \\
competence, request strategies, \\
discourse completion test \\
Corresponding Author: \\
Gede Eka Wahyu \\
Email: \\
eka.stpbispb14@gmail.com \\
DoI: \\
https://doi.org/10.24843/JH.20 \\
21.v25.i02.p03 \\
\hline
\end{tabular}

\begin{abstract}
Communicative competence has been the goal teaching of a second or foreign language. In acquiring the language, speakers of language also acquire the rules of knowledge and choose the speech acts when communicating with others. This study aimed to investigate the act of request strategies and request perspectives produced by the student of The International Institute of Tourism and Business Denpasar. There are fifty students' involved in the study with intermediate level in their English proficiency. The data is collected with a written Discourse Completion Test (DCT) which has ten request situations. Soshana Blum Kulka and Olshtain's (1984) theory is used to categorize the speech acts produce in analyzing data. The result of the project showed that most of the students use internal modification and the number of students external modification in their speech acts.
\end{abstract}

\section{INTRODUCTION}

Communicative competence has been the goal teaching of a second or foreign language for years. Since it is announced by Dell Hymes (1972) communicative competence is the ability of people to communicate appropriately with others. It means that people use language not only in grammatical competence but also in the social context. In other words, knowing the rules of grammar and possessing vocabularies is not enough in communication, it requires social and cultural. Learners need to know how to use their knowledge of grammar and vocabulary depending on the context when they communicate with others. This type of competence called pragmatic competence and it is being a part of communicative competence. Pragmatic competence becomes an important thing in language learning because learners who have grammatical knowledge and vocabulary unable to communicate well in the language they have learned.

Pragmatic studies being a part of language teaching as cited in Bardovi \& Griffin (2005), pragmatic has become a major field in its own right, in linguistic, and now in language learning and teaching. Pragmatic competence has come to be viewed as an essential part of learners' competence. Pragmatic 
competence can be seen through the realization of speech acts which are actions performed via utterances such as requests, apologies, complaints, invitations, and so forth. (Yule, 1996, p. 47).

According to the explanation above there are several problems to find out in the study, they are: 1) what kind of request strategies produce by EFL learners', and 2) How they produce the request speech act. Based on the introduction describe previously, the goal of the pilot project is to discover the strategies of request and request perspectives produce by EFL learners' in the International Institute of Tourism and Business Denpasar. Moreover, this study aims to find out the pragmatics awareness of the students when they used English in a conversation.

\section{METHOD AND THEORY}

The study is taken by the International Institute of Tourism and Business (IPBI) Denpasar. There are fifty students with intermediate levels in their English proficiency involve in the project. Those students never take any TOEFL or TOEIC scores. The instruments used in collecting data were the DCT questionnaires which provide numbers of the situation and have blank space where the student wrote down their appropriate linguistic form of request act.

The participants were secondsemester students of the Four Diploma in Hotel Management program. The students have to fill out the blank space of DCT with the request. There are ten requests with the different situation have to fill out by the students.

The situational variable depends on the social distance (stranger, acquaintance, or friend) and social power (equal status or superior status) were embedded. Based on the situations the participants' asked to produce request speech act in the blank space. Notedtaking was used in collecting data. The researcher read the DCT that was filled out by the students. Then, take note of the type of request strategies produced by the students. After that, classified the request perspective produced by the students.

A descriptive qualitative method was used in analyzing the data. The researcher identifying types of request strategies and request perspectives produced by the students. The results were presented using formal and informal methods. The formal method presented data using statistics and graphs, while the informal method presented the data using the sentence chronologically and in detail (Sudaryanto. 2015).

\section{Theoretical basis}

There were a number of research studies used as references to support this study. The first study was conducted by Eva Ogiermann, et al. 2020. The title An Interlanguage Study Request Perspective: Evidence from German, Greek, Polish and Russian Learners of English. Their study examined request perspectives produced by 900 speakers from nine different languages. Five groups of native speakers of English, German, Greek, Polish, and Russian, and four groups of advanced learners of English as a foreign language (German, Greek, Polish, and Russian). The result shows that most English learners used more conventionally indirect forms than the native.

The second study was conducted by Nina Dascalovska, et.al. 2016. The title of the study is The Use of Request Strategies By EFL learners. The purpose of the study to discover the request strategies produced by EFL learners in the Republic of Macedonia. The participants were students of English at an intermediate level of proficiency. Role-plays and Discourse Completion tests were used as the instrument of the study. The result shows most of the strategies were query preparatory. 
The third study was conducted by Adista Nur Primantari, et.al. 2017. The title Tindak Tutur Meminta Oleh Pembelajar BIPA Dari Korea: Kajian Pragmatik Bahasa Antara (Interlanguage Pragmatics). The data was taken through direct observation by recording and taking note of conversations between Korean who live in Yogyakarta to study the Indonesian language. The result shows that Korean produced different request forms than natives. The difference in requests is mainly caused by linguistic and non-linguistic factors.

\section{Pragmatics}

Crystal (1997, p,301) define pragmatics as "the study of language from the views of the user, especially the choice they make, the constraints they encounter in using language in social interaction and the effect their use of language has on other participants in the act of communication". In other words, pragmatics is defined as the study of communicative action in its sociocultural context. Communicative action includes not only using speech acts (such as apologizing, complaining, complementing, and requesting) but also engaging in different types of discourse and participating in speech act events of varying length and complexity (Kasper and Rose, 1999).

\section{Request acts}

Request are face-threatening acts in which both speakers and hearer's faces at risk, because, by making the request, the speaker impinges on the hearer's claim to freedom of action and freedom to imposition (Brown and Levinson, 1978). The recipient may feel that the request is an intrusion on his/her freedom of action or even a power play. As for the requester, he/she may hesitate to make a request for fear of exposing a need or out of fear of possibly making the recipient lose face (Blum-Kulka et al.,1989, p.11).
One way for the speaker to minimize the imposition is by employing indirect which sounds more polite than direct ones. There are three major levels of the directness of request strategies as describe by Blum-Kulka and Olshtain (1984, pp.201-202). They are:

a. Direct strategies (marked explicitly as request, such as imperative)

b. Conventional indirect strategies (referring to contextual precondition necessary for its performance as conventionalized in the language)

c. Non-conventionally indirect strategies (hints) (partially referring to the object depending on contextual clues)

The three levels of strategies then divided into sub-levels of strategy types as describes in table 1. The first up to five strategies belong to the direct level, the next two belong to the conventional indirect level and the last belong to the nonconventional indirect level.

Request categories proposed by BlumKulka \& Olshtain (1984)

\begin{tabular}{|c|c|c|}
\hline No & $\begin{array}{c}\text { Descriptive } \\
\text { Category }\end{array}$ & Example \\
\hline 1 & Mood Derivable & $\begin{array}{r}\text { Clean up the } \\
\text { kitchen }\end{array}$ \\
\hline 2 & Performative & $\begin{array}{l}\text { I'm asking you } \\
\text { to move your car }\end{array}$ \\
\hline 3 & $\begin{array}{l}\text { Hedge } \\
\text { performative }\end{array}$ & $\begin{array}{l}\text { I would like to } \\
\text { ask you to move } \\
\text { your car }\end{array}$ \\
\hline 4 & $\begin{array}{l}\text { Obligation } \\
\text { statement }\end{array}$ & $\begin{array}{l}\text { You'll have to } \\
\text { move your car }\end{array}$ \\
\hline 5 & Want statement & $\begin{array}{l}\text { I want you to } \\
\text { move your car }\end{array}$ \\
\hline 6 & $\begin{array}{l}\text { Suggestive } \\
\text { formulae }\end{array}$ & $\begin{array}{l}\text { How about } \\
\text { cleaning up? }\end{array}$ \\
\hline 7 & $\begin{array}{l}\text { Query } \\
\text { preparatory }\end{array}$ & $\begin{array}{l}\text { Would you } \\
\text { mind moving } \\
\text { your car? }\end{array}$ \\
\hline 8 & Strong hints (A) & $\begin{array}{l}\text { You've left the } \\
\text { kitchen in a right } \\
\text { mess }\end{array}$ \\
\hline 9 & Mild hints (B) & $\begin{array}{l}\text { We don't want } \\
\text { any crowding( } \\
\text { as a request to } \\
\text { move the car }\end{array}$ \\
\hline
\end{tabular}


Request acts usually include a reference to the requester, the recipient of the request, and/or the action to be performed. The speaker can manipulate the request by choosing from a variety of perspectives ( Blum-Kulka, S., House, J., and Kasper, G., 1989) in making the request. The variety of perspective in requesting follow:

a) Hearer oriented (emphasis the role of the hearer)

Example Could you clean up the

kitchen, please?

b) Speaker oriented (emphasis on the speaker's role as a requester)

Example Can I borrow your notes

from yesterday?

c) Speaker and hearer oriented (inclusive strategy)

Example So, could we tidy up the kitchen soon?

d) Impersonal a bad

For example, so, it might not be

the idea to get it cleaned up.

In addition, the other mitigation of request which can be internal modification is syntactic downgrader. There are some variations in these structures for instance interrogative, negation, past tense, and if clause. The other is another downgrader such as consultative device, understater, hedge, and downtowner. The upgrader is the other perspective of request in which the speaker also has available means by which to increase its compelling force. There are two types of upgrade intensifiers and expletives. The external modification does not affect utterance used for realizing the act, but rather the context in which it is embedded, and thus indirectly modifies illocutionary force. Some categories are checking on availability, getting pre-commitment, grounder, sweetener, disarmer, and cost minimizer (Blum-Kulka and Elshtain, 1984, p. 203-205).

\section{RESULT AND DISCUSSION}

The analysis of participants' responses was based on the type of request strategies proposed by Blum Kulka (1984). Table 1 shows the types of request strategies used by participants.

Table 1 Request strategies

\begin{tabular}{clc}
\hline No & Request strategies & Amount \\
\hline 1. & Reference to & 290 \\
& Preparatory & \\
& conditions & \\
2. & Syntactic downgrader & 79 \\
3. & Subjectivizers & 59 \\
4. & Grounder & 40 \\
\hline
\end{tabular}

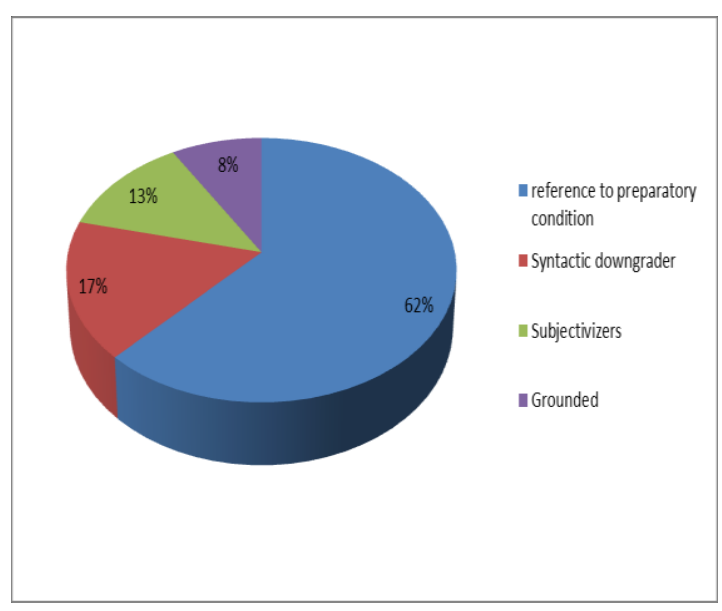

\section{The graph of request strategy}

Based on the table above, most of the participants frequently used preparatory strategies in their request acts. It can be seen from the number of request strategies produce in the DCT. With the respect to request modification as the basis of categorization in the study, it was classified into two, they are internal and external modification. As the result shows, most of the responses used internal modification (a reference to preparatory conditions 290 or $62 \%$, syntactic downgrader 79 or $17 \%$, and subjectivized 59 or $13 \%$ ), while the other 
participants used external modification (grounded 40 or $8 \%$ ) to produce a linguistic form of request strategies.

Most of the students used references to the preparatory condition when they produce the request strategy. The device that used in the strategy were modal verb such as can, could, and may. Example

a. Can I borrow your book?

b. Could you fill out the registration card?

c. May I know your name, please?

The students mitigate the request act in syntactic means as well. They used the phrase would you mind as a device in their utterances. Example

a. Mrs. Elizabeth, would you mind settling half of the hotel payment?

b. Excuse me, Miss, would you mind if I clear up the table.

The rest of the students were used subjectivization in their request strategy. Subjectivizers are defined as elements in which the speakers express a lower assertive force of request (Blum Kulka, et al. 1989). The expression I wonder was used as a device in the utterance. For example, I wonder if you could help me to replace my job.

Some students were used an external modification to produce request acts. They used a clause in precede or follow the request act. This type of modification is called a grounder. A grounder is defined as a clause that can either precede or follow a request and allow the speakers to give a reason, explanation, or justification for their request (Blum Kulka \& Olshtain, 1984). Example

a. Tomorrow is my ceremony, would it be ok if I take one day off?

b. Could you replace my job tomorrow because I want to take one day off?

Table 2 shows the request perspective used by the participant, it showed that most of the responses in all situations use a speaker-oriented perspective (Blum Kulka et. al,1989).

\section{Table 2 Perspectives strategies}

Blum Kulka (1989) categorized three perspectives of requests based on the role of the speech event. In the study, participants applied two types of request perspectives, they were hearer-oriented and speaker-oriented. Speaker-oriented were frequently used in the request act as follows.

\begin{tabular}{clc}
\hline No & $\begin{array}{l}\text { Request } \\
\text { perspectives }\end{array}$ & Amount \\
\hline 1. & Hearer oriented & 73 \\
2. & Speaker oriented & 140 \\
\hline
\end{tabular}

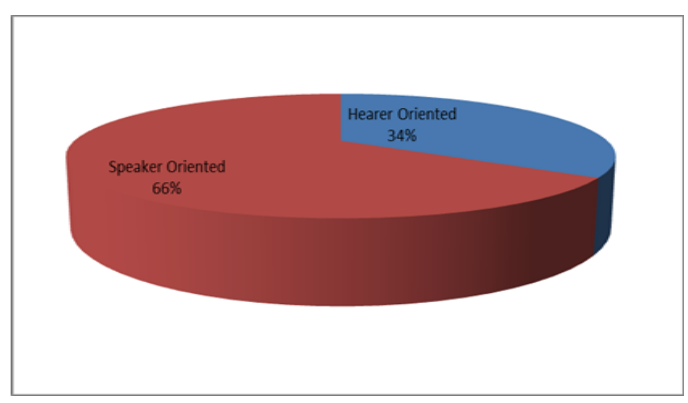

The graph of perspective request

The graph above shows that most of the participant were used the speaker oriented, it means that in the utterance emphasis on the speaker roles as the requester. It can be seen from the utterance as follow.

a. Can I borrow your book?

b. Miss Elena, would it be OK if I clear up your table?

c. Could I borrow your identity card, please?

The utterances $(a, b, c)$ have sound as asking for permission respectively from the speaker to be done. The other respondents have used the heareroriented when they produced request strategies. Hearer-oriented means that the utterance emphasis the role of the addressee. It can be seen from the utterances as follow.

a. Could you fill out the registration for me, please? 
b. Would you mind if you replace my job?

c. Can you lend me your book?

The utterances $(a, b, c)$ have to sound as a conventionally indirect strategy in the imperative form, that the speaker needs the addressee to do something respectively (Blum Kulka et. al, 1989).

\section{CONCLUSION}

Based on the result found in the research, it can be concluded that most of the students of the International Institute of Tourism and Business Denpasar tended to use internal modification strategies in their request act. Those modifications are a reference to preparatory conditions, syntactic downgraders, and subjectivization. The other modification is grounder as an external modification.

Students were familiar with this modification particularly preparatory conditions because they used the strategies daily in the practice situation in the lab both restaurant or in the front office lab.

\section{REFERENCES}

Blum Kulka, S \& Olshtai, E. (1984). Request and Apologies: A Cross Culture Study of Speech Act Realization Pattern (CCSARP). Applied Linguistics. Vol, No.3

Blum Kulka, S et.al. (1989). Cross Culture Pragmatis: Request and Apology. Norwood, NJ: Ablex

Brown, P \& Levinson, S.C. (1987). Politeness: Some Universal in Language Use. Cambridge. Cambridge University Press.

Crystal, D. (1997). English As A Global Language.Cambridge.Cambridge University Press.
Gabriel Kasper \& Kenneth, R. Rose. (1999). Pragmatics in Language Teaching.

Cambridge. Cambridge University Press.

Harlig, B.K \& Griffin, R. (2005). L2 Pragmatic Awareness: Evidence from The ESL Classroom. Elsevier. Vol 33, No.3

Hymes, D. (1972). On Communicative Competence. In J.B Prides \& J. Holmes: Sociolinguistics. Harmondsworth. Penguin

Nina Daskalocska et.al. (2016). The Use of Request Strategies By EFL Learners.

Procedia-Social and Behavioral Science. 55-61.

Ogiermann, E. \& Bella, S. (2020). An Interlanguage Study of Request Perspective: Evidence from German, Greek, Polish and Russian Learners of English. Contrastive Pragmatics. ResearchGate.

Primantari, A.N \& Wijana, I Dewa Putu. (2017). Tindak Tutur Meminta Oleh Pembelajar BIPA Dari Korea: Kajian Pragmatik Bahasa Antara (Interlanguage Pragmatics). Jurnal Penelitian Humaniora. Vol 18. No 1.

Sudaryanto. (2015). Metode dan Teknik Analisis Bahasa. Yogyakarta. Sanata Darma University Press.

Yule, G. (1996). Pragmatics. Oxford. Oxford University Press. 